\title{
Towards an expansive object and a restrictive experience in Everyday Aesthetics: A Chestertonian metaxological approach
}

\begin{abstract}
This article proposes to resolve an internal ambiguity in the subdiscipline called Everyday Aesthetics (EA), systematized by the researcher Horacio Pérez-Henao, according to whom the extension of aesthetics to the everyday has been done, on the one hand, by means of a consideration of an expansive object and subject according to aesthesis itself, as mainly proposed by Katya Mandoki, and, on the other hand, by means of a restrictive object and subject according to the parameters of an authentic aesthetic experience, a theory headed by John Dewey. Methodology: To resolve this tension, a hermeneutic methodology known as the fourfold sense of being, related to Hegelian dialectic, albeit with important modifications supplied by William Desmond was used. This methodology allows a suitable way to explore and discuss different approaches in everyday aesthetics epitomized by Mandoki and Dewey, and makes possible the proposal of a third way, epitomized by G. K. Chesterton. Results: Bearing in mind the original intention of EA-according to which the everyday must be revitalized from an aesthetic perspective, as explained by Joseph Kupfer, it is argued that the two alternate positions of Mandoki and Dewey are unsatisfactory; an attempt is therefore made to respond to this through the analysis of the aesthetic approach of G. K. Chesterton. From his aesthetic reflections, it can be ascertained that to revitalize daily life, the object must be expansive and the subject, restrictive, from a certain méthodos and according to patterns that qualify an everyday aesthetic experience. All of this seeks to pave the way for subsequent investigations of EA being both expansive and restrictive. Finally, it is argued that this Chestertonian EA converges with and extends the aesthetics of design of Jane Forsey, and thus shows that design itself can be revitalized in keeping with a restrictiveexpansive approach to everyday aesthetics. Conclusion: aesthetics should be expansive every day, in that it should concern itself with any aspect of daily life, and restrictive, in that it should set certain limits on the self and its intentions with regard to the possibilities of aesthetic experience.
\end{abstract}

Miguel A. Romero-Ramírez

Magíster en Filosofía Contemporánea Integrante del grupo de investigación LUMEN

Profesor de la Universidad Sergio

Arboleda. Bogotá, Colombia.

Correo electrónico:

miguel.romero@usa.edu.co

(D) orcid.org/0000-0002-7678-3211

Google Scholar

Duncan Reyburn

Doctor en Estudios Visuales Investigador y profesor de la Universidad de Pretoria. Pretoria, Sudáfrica. Correo electrónico: duncan.reyburn@up.ac.za () orcid.org/0000-0002-6753-3368 Google Scholar

Recibido: diciembre 3 de 2019 Aprobado: abril 5 de 2021

Key words:

Everyday Aesthetics, expansive object, restrictive subject, design aesthetics, G. K. Chesterton. 


\section{Hacia un objeto totalizante y una experiencia restrictiva en la Estética de lo Cotidiano: un acercamiento metaxológico y chestertoniano}

\section{Resumen}

El artículo propone resolver una ambigüedad interna a la subdisciplina de la Estética de lo cotidiano, según el cual la ampliación de la estética a lo cotidiano se ha hecho, por un lado, por medio de una totalización del objeto y del sujeto según lo propio de la aesthesis como lo propone, principalmente, Katya Mandoki; y, por el otro, por medio de una restricción del objeto y del sujeto según los parámetros de una auténtica experiencia estética, teoría encabezada por John Dewey. Metodología: para resolver esta tensión se utilizó una metodología hermenéutica conocida como el cuádruple sentido del ser o metaxología, relacionada con la dialéctica hegeliana, pero con importantes modificaciones sustentadas por William Desmond. Metodología que permitió un adecuado camino para la exploración y discusión de los acercamientos contrapuestos en la estética cotidiana, encabezados por K. Mandoky y J. Dewey; y, al mismo tiempo, posibilitó la propuesta de una tercera vía, desde la obra de G. K. Chesterton. Resultados: teniendo en cuenta la intención original prescriptiva que distingue a la Estética de lo cotidiano — según la cual se deben revitalizar los singulares cotidianos desde una perspectiva estética, como lo explicitó Joseph Kupfer-, se discuten las dos posturas contrapuestas argumentando que ninguna de ellas satisfice la intención original de esta subdisciplina y se responde a esta ambigüedad por medio del análisis de los planteamientos estéticos chestertonianos. A partir de sus reflexiones estéticas se puede sostener que, para que se revitalicen los singulares cotidianos a partir de la estética, el objeto debe ser totalizante y el sujeto debe tener ciertas restricciones, entendidas éstas como ciertos méthodos y parámetros. Todo lo cual, dispone ahora un camino investigativo, subsiguiente para la Estética de lo cotidiano al estilo chestertoniano. Finalmente, se argumenta que este modo chestertoniano de hacer estética de lo cotidiano converge y se amplía con la estética del diseño de Jane Forsey $y$, por tanto, esto muestra que es posible revitalizar ciertos aspectos del diseño de acuerdo con un acercamiento restrictivo-totalizante en la estética de lo cotidiano. Conclusión: la estética cotidiana debe ser expansiva, esto es, a todo lo que concierne al aspecto de la vida diaria, y restrictiva, según ciertos límites e intenciones del sujeto para posibilitar una experiencia estética.
Palabras clave:

Estética cotidiana, objeto expansivo, sujeto restrictivo, estética del diseño, G. K. Chesterton. 


\section{Introduction}

In his article, "The place of aesthetics in daily life: a history of the concept of everyday aesthetics, ${ }^{\prime 1}$ after a rigorous historical systematization concerning the configuration of everyday aesthetics, Horacio Pérez-Henao (2014) concludes that this recently introduced sub-discipline of analytical aesthetics has been rooted in a somewhat ambiguous foundation. It still needs some refinement, Pérez-Henao contends, owing especially to unresolved conflicts between scholars in the field. Nevertheless, as proposed by Kupfer (1983), there is a common purpose in opening aesthetics up to the question of everyday experience, namely the aim of encouraging an aesthetic awareness of daily things. In general, "ideas about everyday aesthetics describe the possibilities of aesthetic experience (not necessarily artistic) in the immediacy of everyday life" (Pérez-Henao, 2014, p. 229, our italics). Still, there is no consensus on how this 'opening' should take place. Pérez-Henao (2014) therefore highlights "the need for new studies and reflections specifying whether everyday aesthetics should be expansive (dealing any aspect of daily life) or restrictive in their possibilities of aesthetic experience" (p. 242, our italics).

This implicitly ${ }^{2}$ supposes that before the varied theories on everyday aesthetics emerged (Brady, 2012; Dewey, 2005; Irvin, 2008-2009; Kirshenblatt, 1995; Kupfer, 1983; Leddy, 2012; Mandoki, 2006-2013; Melchionne y Pérez-Henao, 2017; Principe, 2005; Saito, 2007-2017; Sartwell, 1995), two predominant approaches have been adopted: one, expansive, and the other, restrictive. Should everyday aesthetics be expansive or restrictive? Another question naturally follows: Is an approach that transcends and includes both, possible? All of this implies the following tasks, which are addressed below. The first involves explaining both approaches. The second involves discussing the

\footnotetext{
'In both Spanish and English there has been no agreement on the name of this sub-discipline. Sometimes it is referred as "Everyday aesthetics" (Estética cotidiana), sometimes as "Aesthetics of everyday life" (Estética de lo cotidiano).

${ }^{2}$ In Pérez-Henao's article these two modes are not explicit.
} 
merits of each, especially considering the fulfilment of the initial requirement of this sub-discipline. In fulfilling the second task, a third proposal emerges that begins to answer the second proposed question above, namely an approach that mediates between the above-named 'opposing' perspectives.

Such an exploration has a direct bearing especially on the philosophy of design. While the issue of the relationship between aesthetics and design is a common focus in much research, the question of the relationship between design and the sub-discipline of everyday aesthetics has remained largely unexplored, despite the fact that design is predominantly concerned with more commonplace dimensions of experience (See for example Betts, 2004). With this in mind, this article seeks to address two theoretical lacunae: the first is the matter of how to establish a foundation for everyday aesthetics, and the second is the matter of precisely how this may support thinking about the relationship between design and everyday aesthetics. ${ }^{3}$ Regarding the latter, for the sake of retaining a narrow focus and thinking through the application of the philosophical ideas under discussion, the discussion below also pays attention to the scholarship of Jane Forsey.

\section{Methodology}

The hermeneutic methodology adopted for the exploration of the differences of approach in everyday aesthetics is an approach related to Hegelian dialectic, albeit with important modifications supplied by the philosopher William Desmond's so-called fourfold sense of being. Approximately following a Hegelian procedure, this study moves via two distinct ways of dealing with everyday aesthetics, in the first part, towards an evaluation of these ways in

\footnotetext{
${ }^{3}$ As this framing should suggest, with regard to the question of the relation between design and everyday aesthetics, what is said here can only be provisional. Our intention is to open up a specific set of possibilities, especially keeping in mind the possibility of a (Chestertonian) foundation for everyday aesthetics that mediates between the expansive and restrictive modes discussed here.
} 
terms of Desmond's fourfold sense of being, in the second part; and finally, in the third part, it arrives at a third possible approach that resolves and transcends the problems of the first two approaches. As argued below, the resolution suggested here does not strictly conform to Hegelian dialectic, since the end is not a "giving of being" that is merely "given for thinking" (Desmond, 1995, p. 174) but rather is a thinking given for being. Following Desmond, the intention in the end is to retain the dynamic analogical tension between being and its mediation to allow for genuine otherness. To grasp how Desmond's fourfold is applicable to the following, one needs to understand four ways in which being may be mediated: univocally, equivocally, dialectically and metaxologically.

The univocal assumes an immediate meaning in a manner that amounts to an uncontested identity between thought and things (Desmond, 1995, p. 47). This form of mediation is fundamentally "aesthetic" in Desmond's account, in the sense that it reflects an undifferentiated sensuousness - an "overdetermined presenting in our own flesh" that throws the mind into a conformity with its own predisposition towards determination (Desmond, 1995, pp. 47-51). In univocal mediation, subjectivity is entirely active and plays a potentially overly-significant role in mediation. However, an awareness of this over-activity is excluded from this subjectivity. The truth of univocity is in its attunement to being in one particular way, but in the end, the univocal cannot account for itself since even doing so carries intimations of otherness and difference.

Frequently, the univocal is an unconscious response, even a reaction, to the equivocal, which suggests the arising of insurmountable perplexities and which asserts the reign of difference. The equivocal is true to the 'unmediatability' of being - its excessive 'manysidedness,' uncontainability and 'overdetermination' (Desmond, 2014, p. 5). The equivocal resists all forms of determination, and thus places the perceiving subject in a predominantly passive stance, although, 
as with the univocal, still excluding subjective awareness. In this, the subject is rendered porous and receptive to the world, although profoundly limited in regard to a capacity to assimilate. Otherness remains outside and beyond the self.

Hegelian dialectical mediation, as one approach to overcoming the equivocal, tries to resolve the equivocates in being through a mediated recovery of the univocal after the equivocal that amounts to subsuming otherness into pure identity. In the interplay of univocity (identity) and equivocity (difference), the subject arrives at a self-conscious resolution that transcends and includes both forms of mediation. Otherness thus becomes a diversity or plurality within unity (Desmond, 2014, p. 2). As much as this may be productive for much thought, the danger is that it ends up eradicating otherness entirely, since otherness becomes something that must conform to the subject's capacity for mediation. Given this danger, Desmonds proposes the metaxological: the speaking or contemplation of the between-especially the implicit betweenness that exists in any mediation of being-which allows and makes room for the truths elucidated by other kinds of mediation. The metaxological is a speaking of the between that occurs in the perplexing interplay of sameness (mediation) and difference (the unmediatable), and is thus a recovery of the equivocities of being after dialectical mediation.

Desmond's fourfold analysis is uniquely helpful for this research in that it stresses the relation between being and mediation, a concern that gives rise to his own theories on aesthetics not considered here. In considering the mediation of being, Desmond emphasises how particular modes of mediation include and/or exclude certain aspects of being, and thus stresses the importance of recognising, and to some extent maintaining, certain paradoxes and perplexities that arise in our reflections on mediation-including aesthetic mediation (Desmond, 1995, p. xiii). The result is a dynamic philosophical 
framework that nevertheless retains a structure (Desmond, 1995, p. xiii). This suits the following inquiry because it allows us to look for ways in which any given aesthetic theory may be true to being, rather than presenting a false sense of how one aesthetic theory should or should not supplant another. It also presents the possibility of better and worse ways of thinking about everyday aesthetics. Furthermore, this methodological lens takes into account the predominating dialectical logic of design as a problem-solving and reframing framework (e.g. Becket, 2017; Dorst, 2015) while also accounting for the fact that designers themselves cannot be true to being without also being open to surplus meanings that elude their mediations.

In the end, as argued below, the thinker who best exemplifies a kind of metaxological mediation between these approaches is the philosopher G. K. Chesterton, whose work makes up the bulk of two projects by the authors of this article, namely the research project called Civic humanism and cultural tendencies of the LUMEN research group at Sergio Arboleda University (Miguel Romero) and the monograph and other research, including design research and teaching, done at the University of Pretoria, South Africa (Duncan Reyburn). It is in the second phase of this article, dedicated to unpacking Chesterton's aesthetics, that we conclude that his particular approach allows for a productive mediation and solution to some problems around everyday aesthetics not addressed adequately in the two more standard articulations.

For the first two parts of this article, and to make the proper selection of authors, a survey was made of databases such as Scopus, Istor and ScienceDirect with the terms 'aesthetics + everyday'. Authors were then grouped within the two approaches: a. Expansive or b. Restrictive. Finally, a depuration of authors was made on two conditions, first with regard to who has made a fundamental theorization around the aesthetics of everyday life (a non-operative approach); and secondly, with regard to whether the theorization instituted operative 
ways of developing everyday aesthetics, or because its theorization combined previous operative ways. The two authors who fulfilled the above requirements were the philosopher Katya Mandoki, whose approach is expansive, and the philosopher John Dewey, who adopts a restrictive approach.

In the end, this study proposes certain novelties. On one hand, it seeks to mediate between the two apparently opposing positions within the study of everyday aesthetics to provide a basis of fundamental attitudes and patterns inherent in this sub-discipline. On the other hand, it tries to fill in certain bibliographic deficits with regard to the consideration of Chesterton's aesthetics (Romero, 2019). Moreover, it explicitly brings Chesterton's thinking into design scholarship. While it is true that Chesterton neither explicitly formulates an aesthetic approach nor makes aesthetics an explicit concern in the way that contemporary scholarship has made it, it is nevertheless obviously fundamental to his work and, thus, potentially generative with regard to developing thinking around everyday aesthetics more fully. It is also clear that it has a bearing on design itself, which is arguably best thought of along the lines of paradoxical or metaxological mediation (Reyburn, 2008).

\section{Results}

\section{Everyday aesthetics: expansive and restrictive approach}

\subsection{Expansive everyday aesthetics}

Expansive everyday aesthetics upholds the thesis that all aspects of daily life must be brought into aesthetic consideration under the concept of "aesthetics". The theorist who most clearly and radically sustains this totalization is Katya Mandoki (2006) who considers aesthetics a "theory about stesis or sensibility" (p. 189). This definition leads to an extension of 'aesthetics' to everything 
that is part of the subject's sensitivity. Thus, aesthetics no longer consists in achieving a different quality from ordinary experience because experience (as aesthesis) is already an aesthetic activity (Mandoki, 2007). This perspective is also supported by scholars who promote expansive aesthetics by removing all traditional aesthetic restrictions (Leddy, 2012; Saito, 2007; Melchionne y Pérez-Henao, 2017), because deferring to aesthetic idealizations would give rise to a new world of aesthetic considerations (Contreras, 2019).

This proposal concerning expanding aesthetics naturally implies the removal of certain obstacles maintained by certain articulations of traditional aesthetics. According to Mandoki (2007), for example, aesthetics must overcome the "fetishes" of considering beauty, artworks and aesthetic objects as exclusive to the field of aesthetics. Maintaining such distinctions, for Mandoki, implies restricting aesthetics to very limited objects. In addition, she proposes that certain aesthetic 'myths' must be overcome, such as conceiving beforehand that there is an opposition between art and reality, or that art and aesthetics are synonymous; or other myths according to which it is essential to have an aesthetic disinterest, or an aesthetic distance, or an aesthetic attitude, or an aesthetic experience (Mandoki, 2007). All of these, Mandoki suggests, must be overcome.

This approach, however, does not promote any kind of addition to everyday experience since, according to Mandoki's definition and understanding of aesthetics, to speak of aesthetic experience is redundant. In her view, all experience is aesthetic. Mandoki affirms, against Dewey's perspective discussed below, that "all experience is aesthetic by definition because to experience is equivalent to aesthesis" (Mandoki, 2007, p. 35).

Moreover, Mandoki contends that an expansive aesthetics must also overcome the "fears" that could derive from it, implying that there is room for the 
unpleasant and even the immoral, or at least the ethically contested. Mandoki (2007) proposes that: "[it] is necessary to include not only the agreeable into aesthetic appreciation, but [also] the disagreeable, since, far from missing our objective, it would allow us to explore the aesthetic dimension through all corporeal senses" (p. 39). Similarly, "it is necessary to confront the fear of the immoral in the research of aesthetic phenomena, and overcome the calculated naïveté of attributing it an exclusively virtuous character" (Mandoki, 2007, p. 41). In fact, the devil's attraction can enter into the sensitive mêlée because "this attraction, perverse or not, amoral or immoral, is aesthetic, embarrassing as it may be" (Mandoki, 2007, p. 40).

If the above-named obstacles are removed, as Mandoki recommends they should be, then aesthetics can be expansive. Expansive aesthetics can then be summarized as an extension of aesthetic considerations to all objects of subjective aesthesis. The aesthetic experience, then, does not have an inclination to break with the everyday. Thus, Mandoki: "[I]s the aesthetic really extraordinary? Quite the contrary: the aesthetic is, in fact, the most common, everyday and indispensable activity we perform throughout our life" (Mandoki, 2007, p. 67).

It appears that traditional aesthetic restrictions disappear because neither objective nor subjective characteristics are required for anything to be aesthetic. In the end, "the aesthetic is related to experience as the lived dimension of reality without necessarily implying any relation to beauty or pleasure" (Mandoki, 2007, p. 74). As a result, everyday aesthetics has the aim of studying aesthetic mechanisms and their effects upon sensitivity-matters that are taken up by the Mexican philosopher in her works (Mandoki, 2007, 2013). When filtered through the mode of analysis proposed by Desmond, Mandoki's view represents the unmistakably univocal, although inevitably there are intimations of equivocity, too. By obliterating aesthetic boundaries and limits, 
Mandoki suggests a certain proportion between subject and object and thus also tends to presume an absence of mediation. Genuine otherness is disavowed.

As this paradigm would suggest, the subject's perceptions univocally equate to being. The subject actively mediates being but this activity is rendered as a radical openness in Mandoki's work, which obscures the decisive role of the subject in aesthesis. Put more succinctly, what appears is all there is for the subject. Desmond points out, of course, that the univocal is true to being, since many of our experiences do not appear to us to contain hints of otherness or of our part in mediation. The aesthetic can, in this sense, be expansive. Nevertheless, it would be a mistake to stop there; that is, to presume that the aesthetic is nothing but expansive. Mandoki's account is true to being, but incompletely. In synthesis, therefore, this expansive aesthetics can be systematized as follows, regarding the formal object, the material object, its objective, and its claims upon normativity:

1. The formal object: aesthetics is understood as a theory of sensitivity. The expansive subject: is thus merely a subjective aesthesis. Mediation is presumed to be absent.

2. The material object: the everyday is understood as the space in which the subject's aesthetic conditions unfold.

3. The objective is to study the aesthetics already present in the subject's daily behavior and structures.

4. It does not have a normative aim with regard to the experience of daily living because that experience is already deemed aesthetic.

\subsection{Restrictive Aesthetics}

The restrictive approach proposes that daily experience becomes something of an artwork. This cannot happen without considering some restrictive 
conditions that the aesthetic experience must fulfil in everyday life. This first group is headed by John Dewey's reflections in his book Art as experience ([1934] 2005). Based on Dewey's distinction between experience and an experience, some authors (Berleant, 2005; Kirshenblatt, 1995; Kupfer, 1983; Novitz, 1992; Principe, 2005; Sartwell, 1995) affirm that aesthetic analysis must lead to a characterization of aesthetic experience as entirely distinct from normal experience. Consequently, they affirm that the aim of everyday aesthetics is to add to ordinary experience by, for instance, making it aesthetic through immersion, involvement, or commitment. This implies that reflection on everyday aesthetics aims to achieve a greater awareness of the everyday, such as with everyday activities like sports or cooking (Leddy, 2005; Bustacara, 2019), or to convert aspects of the everyday, like home decor, into being artistic elements (Lozano \& Lapeña 2018).

The emphasis of this perspective is on studying the most important conditions of experience from which art emerges and then applying the understanding gained to qualifying one's experience of the everyday. Dewey proposes some conditions presented as fundamental restrictions that are further completed or restructured by the authors mentioned above. These basic conditions proposed by Dewey are unity, consummation, and structure (doing and undergoing).

The first condition of aesthetic experience is unity, referring to the interpenetration of the self and space-time, in which there is an identification between the subject and what is going on. This indicates a determined quality that permeates the experience, making its parts a unique whole allowing the subject to recognize something as an experience, as often happens with art: "in a work of art, different acts, episodes, occurrences melt and fuse into unity" (Dewey, 2005, p. 38). For Dewey, consequently, this aesthetic experience in unity cannot take place in a world in which everything is flow, change, or difference; on the contrary, the aesthetic experience asks for (the possibility of) 
a specific conclusion. This would be the phase in which the experience in development is consummated or completed as the stability of a finished art object. The second condition "is that of a movement of anticipation and cumulation, one that finally comes to completion. A 'conclusion' is no separate and independent thing; it is the consummation of a movement" (Dewey, 2005, p. 39).

Linked with this, the third condition is the interpenetration between doing and undergoing (that is, structure). This third condition refers to the relationship between a living creature and some aspect of the world in which it develops. For this reason, doing and undergoing are an articulation between reception and action or, in other words, between rhythmical exteriorizations and interiorizations (Dewey, 2005). In this way, "the experience itself has a satisfying emotional quality because it possesses internal integration and fulfillment reached through ordered and organized movement. This artistic structure may immediately be felt. In so far, it is esthetic" (Dewey, 2005, p. 40). For instance, a painter "has to see each particular connection of doing and undergoing in relation to the whole that he desires to produce" (Dewey, 2005, p. 47). As this suggests, a qualified aesthetic experience that brings together the three conditions in a balanced way is as follows:

[E]xperience in the degree in which it is experience is heightened vitality. Instead of signifying being shut up within one's own private feelings and sensations, it signifies active and alert commerce with the world; at its height it signifies complete interpenetration of self and the world of objects and events... it is art in germ. Even in its rudimentary forms, it contains the promise of that delightful perception which is esthetic experience. (Dewey, 2005, p. 18)

That said, Dewey is skeptical of the possibility of a qualified aesthetic experience in everyday life because daily life is usually not something that conforms with such demands: "No one experience has a chance to complete itself because something else is entered upon so speedily. What is called experience becomes 
so dispersed and miscellaneous as to hardly deserve the name" (Dewey, 2005, p. 46, our italics). Sometimes in an everyday experience, the following occurs:

There are beginnings and cessations, but no genuine initiations and concludings. One thing replaces another, but does not absorb it and carry it on. There is experience, but so slack and discursive that it is not an experience. Needless to say, such experiences are anesthetic. (Dewey, 2005, p. 41)

The result of this is that, an experience, in a restrictive aesthetic, may not turn out to be genuinely aesthetic. Just experiencing is not enough to have a qualified aesthetic experience, because "there are conditions to be met without which an experience cannot come to be" (Dewey, 2005, p. 45). Thus, restrictive aesthetics can be systematized in the following terms:

1. Formal object: aesthetics, understood as the theory of qualified aesthetic experience (restrictive subject). Mediation plays an overly active role.

2. Material object: the everyday, understood as an art configuration (restrictive object).

3. Its objective is to study the restrictive structures that promote a qualified aesthetic experience in everyday life.

4. Its purpose (or normative aim) is to achieve an experience in everyday life.

\section{Discussing Mandoki's expansive and Dewey's restrictive aesthetics}

The following discussion arises from the original intention of Joseph Kupfer (1983), who was the first to coin the concept, "aesthetics of everyday life". The aim of everyday aesthetics, as he originally conceived of it, must be to have a greater awareness of everyday life, with its daily objects and activities (Kupfer, 1983). Faced with this original intention, ${ }^{4}$ both perspectives-expansive and restrictive-face some problems, some of which have already been hinted at.

${ }^{4}$ Kupfer did not make a theoretical foundation, but he developed an aesthetics of everyday life in an operative way, analyzing education, violence, morality, sex, sports, decision-making and death. 
Bear in mind, ahead of our mentioning more detail, that the third part of this discussion assumes the partial validity of some aspects of these approaches but nevertheless seeks a form of mediation that is more apt at resolving these problems.

First, the main problem with regard to Mandoki's approach, is that the expansive aesthetic does not revitalize everyday life. It is true that it opens up space for the everyday through sensibility, but it risks trivializing everyday life, since the everyday remains at the same level as the ordinary and common. For Mandoki, there is neither an addition nor any particularity to daily aesthetic experience. An aesthetic subject would consist simply in living; that is, in being corporeally melded in space-time (Mandoki, 2006). Moreover, in Mandoki's reductive conception of aesthetics to sensitivity (including removing fetishes, myths, and fears), the basic or fundamental elements of aesthetics are lost i.e. their relationship — whatever that may be — with beauty and its qualities (Yarza, 2004). In this order of ideas, it would not make sense to speak of "aesthetics" since there would not be something that distinguishes it from other competencies. ${ }^{5}$

In this, as already hinted, there is something of a univocal determination in Mandoki's work, as evidenced by the flattening-out of all distinctions. The resultant homogeneity is precisely why the aesthetic is ultimately excluded from her paradigm: genuine otherness becomes, if not completely unthinkable, then certainly unwanted. However, predictably, univocal determination is quickly followed by the equivocal; that is, an over-readiness to embrace what is debased and/or shocking. However, since the debased is pre-emptively submerged under an a priori commitment to univocity, it is more likely for an experience of its otherness to be horrific rather than aesthetic. Horror, not wonder, becomes the expected normal circumstance.

${ }^{5}$ The same applies to the apparent redundancy of the "aesthetic experience". This redundancy would eliminate in a reductionist way the plurality of the diverse human experiences such as scientific or moral experiences. 
Because giving place to the immoral does not imply any genuine addition to everyday experience in the way that expansive aesthetics may seem to hope for, it is trivialized since there is only reference to sensibility, not to beauty. Thus, the immoral is placed on the same level as any feeling (aesthesis) derived from encountering something good or beautiful. What matters, given the inherent enclosedness of univocal determination, is the subject's sensitivity. Thus, the aesthetic subject, in an expansive aesthetics, could simply be any sentient being. Additionally, it is common for the subject's sensitivity to be found atrophied. Without something akin to objective values, this sensitivity soon falls into apathy or anaesthesia where evil or grotesqueness might become banal (Arendt, 2006; Smith et al. 2021).

Then, as if to attempt to resolve the univocal reaction to equivocities in being, is Dewey's aesthetic proposal, which consists fundamentally in transporting the conditions of the artistic experience (unity, structure, and consummation) to qualify an aesthetic experience in everyday life. However, in the end Dewey himself falls into a skepticism of its own possibility, since the restrictive conditions are very difficult to achieve in an everyday experience (Dewey, 2005). There is evidence that his dialectical approach in some sense echoes and recovers the univocal, and even hints towards the possibility of the equivocal; however, in the end, the genuine and vital importance of otherness in the aesthetic experience is sidelined. Arguably, this difficulty arrives because these demands are taken from artistic experience, which is different from ordinary experience. Thus, it would probably be better if these restrictive conditions were less complex. In fact, the same sophistication makes a qualified aesthetic experience in everyday life difficult. For instance, English aestheticism shows that an excess of aestheticist conditions (dandyism, intellectual aristocracies, sophisticated poses, contempt for morality as non-artistic) leads to the oblivion of the everyday (Praz, 1988). For example, Dorian, the main character in The Picture of Dorian Gray, who is trying to follow the high requirements of an 
artistic life, does not resist the everyday aspects that are ordinary, arduous, and repetitive; rather, he describes them as mean and boring (Wilde, 2014).

In addition, Dewey suggests that there is no aesthetic experience in the peasant who gets tired and leaves the plow to go on with something else, or in the child who is distracted from his task when he sees a butterfly or a fly passing by, or in the worker whose life is consumed by his labors (Dewey, 2005). These experiences, while sometimes characterized by distraction and alienation, do not necessarily imply inauthenticity or the non-aesthetic. Changes in activities can be initiated by aesthetic requirements; a commonplace occupation can still be full of aesthetic satisfaction. Dewey's critique shows, rather, that his position could still be identified_-albeit vaguely, trying not to fall into anachronisms - with the aristocratic position of the eccentric personalities of English aestheticism who despise the everyday, which includes common folk, ordinary work and poverty (Johnson, 2017).

As the above suggests, Dewey offers something of a possibility that the aesthetic experience must involve a genuine encounter with otherness, although in the end it also seems that the form of mediation found in his work is predominantly dialectical, in an approximately Hegelian sense. This is to say, it reflects what Desmond refers to as an attempt to recover the univocal in the aftermath of equivocal resonance, but does so by risking a turn inwards-rendering being at the service of thought, rather than thought at the service of being. In the end, the aesthetic experience suggested by Dewey involves an absorption of otherness within the same; a movement of fully accounting for the aesthetic by means of the overt command of subjectivity. An a priori overemphasis on the active subject remains in place, almost as much as it does in the work of Mandoki. Since surpluses and equivocities are left beyond the grasp of the perceiving subject, they are not included as part of the experience. Arguably, it is precisely this dialectical account of the aesthetic that makes it restrictive. 
Dewey's approach also tends to place a heavy emphasis on the subject as predominantly active. However, the dialectical movement from self to other to self does suggest at least something of the possibility of a mode of receptivity that is almost certainly absent from the work of Mandoki, whose work shows a tendency to somewhat tranquillize the subject. Thus, in both Mandoki and Dewey, the problem of otherness remains, since the precise relational equivalence between subjectivity and objectivity remains (unconsciously) intact: in Mandoki, the expansive subject must imply an expansive object; in Dewey, the restrictive subject must imply the restrictive object. Thus, in both, subjectivity remains strictly in control, albeit it more actively so in Dewey and more passively so in Mandoki. Ironically, then, both restrictive and expansive approaches create the same problem: the self is situated as a site of mastery in the so-called aesthetic experience. Put differently, Mandoki's and Dewey's accounts of aesthetic experience do not fully account for the aesthetic experience, even when they may hint in the right direction; hence, the need for an approach that might both mediate between and transcend these approaches.

\section{Everyday aesthetics in G. K. Chesterton}

\subsection{Subjective restrictions in Chesterton aesthetics}

The subjective restrictions we find in G. K. Chesterton's aesthetics are basic attitudes. These are fundamental conditions or thresholds (Kass, 2005) from which it is possible to expand aesthetics to everyday life. In fact, these subjective restrictions open a special aesthetic path as a way of approaching the everyday. Such attitudes are a basic configuration in the subject's experience. There are three: contingency-sense (contingens), wonder, and gratitude. 
The first basic attitude is contingency-sense. Chesterton (1874-1936) was immersed at the end of the 19th century in the Victorian pessimism and English Aestheticism characterized by a passive nihilism (Evans, 2011). In October 1893, Chesterton entered the Slade School of Art at the University College in London where the aestheticism of Oscar Wilde, Walter Pater, Joris-Karl Huysmans and George Moore prevailed (Ker, 2011). Chesterton notes that it was a period of his "going to an art school and [was] doubtless also coloured by the conditions of such a place", which was possessed by "a very negative and even nihilistic philosophy" (Chesterton, 2006, p. 96).

However, unlike Victorian and Aesthetic pessimism, Chesterton recovers an anti-nihilistic nothingness by way of affirming that things are. Nothingness is an experience that Chesterton proposes as a vital requirement for taking the next step, namely towards bringing forward everyday realities. Nothingness is an experience towards the world that is constantly involved in it; that is, the possibility of being and the not-being of things. This involves an experience of the contingency of things in the world. Against an imperturbable self, Chesterton affirms that "to me is a more solid and startling fact that any man in the street is a Great Might-Not-Have-Been" (Chesterton, 1986, p. 578). This possibility of being immediately implies the actuality of being: (Chesterton, 2002, p. 104). Indeed, "until we realise that things might not be we cannot realise that things are. Until we see the background of darkness we cannot admire the light as a single and created thing." (Chesterton, 1986, p. 66). Against the naive (univocal) objectivity of his era's scientism, Chesterton wrote in 1908:

The law is not a law. A law implies that we know the nature of generalization and promulgation, not only that we have noticed some of the effects... It is not about laws, because we do not understand their general formulation; nor about needs, because, although we can count on them occurring in practice, we do not have the right to say that this will always happen. (Chesterton, 1986, p. 255) 
Chesterton's critique of scientism is not in favor of childish skepticism. $\mathrm{He}$ is against the metaphysical skepticism of positivism and also of Kantian criticism. His animosity is not towards science as such, but he is against the disenchanting power that it brings when it captures culture (Jaki 1986). He criticizes a Modernism that stages a universe as either chaotic or necessary, since this makes it easy for us to forget the contingent character of beings. Chesterton emphasises the contingency of things, which follows the formula: maybe NOx. This emphasises the possibility of not being, emerging from the proper conceptualization of nothingness as always mediated by a prior givenness. However, it is not the claim of Leibniz's sufficiency argument, despite its apparent proximity, since Chesterton's bet does not correspond to a strict logical deduction tied to the interminable discussions of dialecticians. Instead, it is an existential attitude in which gratitude lies between contingency and necessity. Then, Chesterton says that:

If a man saw the world upside down, with all the trees and towers hanging head downwards as in a pool, one effect would be to emphasise the idea of dependence. There is a Latin and literal connection; for the very word dependence only means hanging. (Chesterton, 2002, p. 247).

This nothingness as contingency-sense prepares us for the second and third attitudes, because what "arises out of this almost nihilistic abyss" is "the noble thing that is called Praise ... [The poet] praises the passage or transition from nonentity to entity; there falls here also the shadow of that archetypal image of the bridge" (Chesterton, 2002, p. 250). Praise brings together wonder and gratitude.

The second attitude, accordingly, is wonder. It comes when being stands out from nothingness: "we can best measure the towering miracle of the mere fact of existence if we realise that but for some strange mercy we should not even exist" (Chesterton, 2002, p. 318). Everyday realities come out as matters not fully explained, with a high degree of mystery and unintelligibility. 
This is even suggested in the very existence of everyday aesthetics as an inquiry, which seeks to raise questions around our engagement with everyday things without reducing that experience to neat dialectical explanations (we agree here with Leddy y Pérez-Henao, 2020). Chesterton proposes to see the reality in the atmosphere of fairy tales in which, although there are logical regularities, there are ontological surprises in the form of a creative non-identical repetition of being (Cf. Chesterton, 2006, p. 264; Pickstock, 2013). In this approach, being is presented, not as ordinary insight, but as nothing obvious. This implies the possibility of wonder at its mysterious magnificence: "The curse that came before history has laid on us all a tendency to be weary of wonders. If we saw the sun for the first time it would be the most fearful and beautiful of meteors" (Chesterton, 1986, p. 128)

Biographically speaking, some writers who Chesterton studied to achieve this perspective were Walt Whitman, R. L. Stevenson, George MacDonald and Charles Dickens. These authors have in common a basic wonder towards reality, and especially the everyday. For instance, Browning sang about the artwork which is the life of each one (Chesterton, 1903), Stevenson wrote about life as an adventure (Chesterton, 1902), MacDonald was decisive for capturing the magical and mysterious heart of reality (Chesterton, 1929, pp. 325-327), and Dickens wrote about the poetry of the city (Chesterton, 1906).

The third attitude, related to wonder, is gratitude. Mariano Fazio has called Chesterton's thought the philosophy of grateful astonishment (Fazio, 2002). Gratitude is understood as a response to the actual being of things in daily life. At the same time, gratitude is the consideration of how valuable and undeserved are all the parts which integrate everyday life. Existence itself is not taken for granted. That is why it is possible to be thankful. It implies an attentive respect towards being. In fact, Chesterton's works may be thought of as a "grammar of gratitude" (See Chesterton, 2002, p. 318). 
Humility is necessary as an accompaniment to this gratitude. Humility consists in seeing reality with reverence. Chesterton notes that humility is "the door of the earth" (Chesterton, 2006, p. 329) that permits us to behave towards reality with finesse and not just with utilitarian ends in mind. It leads us to touch the fragility of being, in other words, "the pricelessness and the peril of life" (Chesterton, 1986, p. 267). In the same way, "until we understand that original dark, in which we have neither sight nor expectation, we can give no hearty and childlike praise to the splendid sensationalism of things." (Chesterton, 1986, p. 128, our italics). This sensationalism is called mooreeffoc:

And there is (especially for the humble) Mooreeffoc, or Chestertonian Fantasy. Mooreeffoc is a fantastic word, but it could be seen written up in every town in this land. It is Coffee-room, viewed from the inside through a glass door, as it was seen by Dickens on a dark London day; and it was used by Chesterton to denote the queerness of things that have become trite, when they are seen suddenly from a new angle. (Tolkien, 1988, p. 77)

All these conditions allow us to fully enjoy everyday things, in the depth of their being. It generates a debt of gratitude that is the response of wonder, as well as a recognition of contingency in everyday life. Chesterton, at the end of his Autobiography, writes that "the doctrine I should always have liked to teach [is] the idea of taking things with gratitude, and not taking things for granted" (2006, p. 325). It restores vigour to everyday life. In synthesis, contingency, wonder and gratitude allow a better appreciation of the daily. Because "the way to love anything is to realise that it might be lost" (Chesterton, 1909, p. 56). Moreover, as Chesterton contends:

The aim of life is appreciation; there is no sense in not appreciating things ... I originally said that a cockney lamp-post painted pea-green was better than no light or no life; and that if it was a lonely lamp-post, we might really see its light better against the background of the dark. (2006, p. 327). 


\subsection{Chesterton's aesthetic patterns}

Some patterns can be deduced from Chesterton's works that suggest an entire environment within which everyday objects exist. The recognition of this environment and the patterns perceptible within it make it possible to regard objects as actual objects of aesthetic analysis and experience. Such objects include things like tram tickets, penknives, matches, chalk, coins, car accidents, sleeping, traveling, diseases, beds, small inconveniences, rain, streets, and so on, as Chesterton has analyzed in some of his works (See especially Chesterton, 1909, 1911). The primary perceptible patterns suggested by Chesterton, each of which implies the recognition and revitalization of everyday life, are the following: the instant, repetition, home (as identity), limitations and the unsightly. These are briefly discussed below.

First is the recognition of the instant, which implies that everyday life is constituted in and even by the present moment. The everyday is ours, occurring now only momentarily, and yet reappearing over and over again in memory. It is this moment that makes insight possible. Chesterton writes: "the vast and shallow philosophies, the huge syntheses of humbug, all talk about ages and evolution and ultimate developments. The true philosophy is concerned with the instant" (Chesterton, 1986, p. 341). This is certainly not the univocal numbing that one finds in Mandoki's work but a call towards the plenitude of being.

Second is repetition, which is related to the instant's contents. Chesterton's everyday aesthetics entail a revitalization of what happens again and again, every day, because this makes up the rhythm of the daily. Unlike English Aestheticism and mechanistic repetition, aesthetic repetition has a character of beauty and constant novelty for Chesterton. In fact, repetition is not a lack of 
life, but an overflow of life and energy; everything appears as pointing beyond the limitations of its own nature towards more:

A child kicks his legs rhythmically through excess, not absence, of life. Because children have abounding vitality, because they are in spirit fierce and free, therefore they want things repeated and unchanged. They always say, "Do it again"; and the grown-up person does it again until he is nearly dead. For grown-up people are not strong enough to exult in monotony. (Chesterton, 2006, p. 264)

Repetition implies a change of attitude. With contingency-sense, wonder, and gratitude it is possible to have something like a divine gaze; indeed, "it is the gods who do not tire of the iteration of things; to them the nightfall is always new, and the last rose as red as the first" (Chesterton, 1986, p. 76). Subtly included in Chesterton's stress on repetition is an increasing sense that things are not merely themselves (univocally or dialectally determined, or merely at the mercy of their own intimations of equivocity) but are poems of the between: all things are for us and yet, also, beyond us, such that we are also for them. Repetition, therefore, functions analogously, as a speaking of the genuine betweenness in being. Repetition shows an ongoing unfolding and opening to surplus meanings beyond dialectical mediation.

Third, the home, metaphorically speaking, is the environment that surrounds and gathers us daily, informing and creating our deepest identity: faces, things, working places, transportation, living place, streets, and so on. All of these are easily caught in the flow of the identification of each one: my family, my friends, my desk, my bed, my book, within the context provided by smells, rhythmic steps, voices, colors, or an image noticed when I look through a window. The home suggests that "life is not a thing from outside, but a thing from inside" (Chesterton 1986, p. 141). It is the contrary of misrecognition or unrecognizability. This is noted in Chesterton's reading of Homer's Odyssey: "Ulysses does not desire to wander at all. He desires to get home" (Chesterton, 1986, p. 142). 
Fourthly, limitations are the particular way as daily life appears, that is, in small things. In fact, for Chesterton, "art is limitation; the essence of every picture is the frame" (Chesterton, 1986, p. 243). In Chesterton's everyday aesthetics things are looked at through a window. While this constrains things, it also ensures that things are seen in their concrete peculiarity. And Chesterton stresses that such limitation does not make a small world. On the contrary, limitation is what makes the world larger, as a microscope does. Thus, Chesterton proposes to do something like the work of microscopists who "study small things and live in a large world" (Chesterton, 1986, p. 126).

Fifthly, Chesterton's everyday aesthetics allow for an obvious truth: some daily things are no doubt unsightly. This must be accounted for given PérezHenao's (2014) contention that the ugly is not part of the everyday aesthetics: "Displeasure, ugliness, unpleasantness, horror or violence, are discarded from an aesthetic gaze in the conceptual configuration of the everyday aesthetics" (p. 240). However, according to Chesterton's approach, which places some limits on Mandoki's negative aesthetics, the unsightly can be part of everyday aesthetics in two senses. First, according to Chesterton's basic posture, certain difficulties can be seen as beautiful in that they can help us to perceive many of the finer qualities of the human spirit. Certainly such difficulties need to be accounted for, since life itself, as a drama of interactions, is difficult; "like all good things, it is full of discomforts, dangers, and renunciations" (Chesterton, 1986, p. 137). Along these lines, Chesterton also highlights the grotesque as a dimension of aesthetic experience but this has more to do with stark contrasts in aesthetic experience, of which Chesterton approves, rather than with something like admitting the vile and immoral as legitimate sources of aesthetic enjoyment (Milbank, 2009, p. 56).

The second aspect of the unsightly accounted for by Chesterton refers to an aesthetic emotion called disgust. This comes from things that gesture towards 
degradation. Violence and horror may be part of everyday life and so naturally enter in aesthetic consideration because of an aesthetic aversion to evil (Knight, 2004). Besides, what is truly against aesthetics is indifference, apathy (dull sensitivity or anesthesia) or a depraved and totally disfigured sensitivity that delights in violence, evil, and suffering. Such an aesthetic sense of disgust is the natural companion of a sensitivity to beauty, and so it is therefore necessary to have an aesthetic education geared towards the appreciation of beauty (Marini, 2021). In this, Chesterton's articulations around the aesthetic take into account how our sensibilities may be true or false with regard to aesthetic experience. His work therefore strongly affirms the place of intermediation, without which one cannot provide a suitable account of everyday aesthetics.

In synthesis:

1. Formal object: aesthetics, understood as the discipline that studies what is related to beauty and its qualities from contingency-sense, wonder and gratitude (restrictive subject).

2. Material object: the everyday, understood as all everyday objects, which are encountered in the instant, the repetition, the home, limitations and the unsightly (expansive object).

3. The objective is to analyse everyday life aesthetically by means of restrictive attitudes and expansive patterns.

4. The normative aim is to revitalise daily life by aesthetic consideration. It is to remain open to the surprise of the ordinary.

\subsection{Convergences between the Aesthetics of Design of Jane Forsey and Chestertonian Everyday Aesthetics}

As noted in the introduction, the present exploration has a direct bearing on the philosophy of design. Thus, this section offers our attempt to articulate, 
albeit briefly, how the above may support thinking about the relationship between design and everyday aesthetics. To do this, our focus is especially on Jane Forsey's (2013) constructive critique of traditional aesthetics from the perspective of design theory, and how this critique converges with our approach. After all, Forsey promotes a revitalization of everyday things for both designers and users. Designers are, if only ideally, aesthetically aware of everyday things and needs, and users are those who choose and use such things to constitute their daily worlds. Of course, Forsey is not alone in considering the relationship between design and everyday aesthetics, but her work is taken here as a case in point because it is one of the best explorations of this relationship to date.

Forsey supports the transverse criticism offered by everyday aesthetics of traditional aesthetics. If aesthetics is restricted to fine arts, it will be a "highly specialized field preoccupied with a phenomenon that has no direct bearing on the lives of a great many of us" (Forsey, 2013, p. 244). However, we usually have aesthetic experiences with daily things, at our homes or at work, because we are consumers, users, creators, and "inhabitants of designed environments" (Forsey, 2013, p. 250), not just spectators or critics. We live between and among things, not as alienated from them by the hermetically sealed "methodological disenfranchisement" offered in "spectator model[s]" of aesthetic engagement (Forsey, 2013, pp. 196-198). Indeed, preempting Forsey somewhat, a Chestertonian approach also wants to overcome traditional aesthetic theories that wrongly restrict objects meant for aesthetic consideration, although this does not imply making "framelessness" absolute, which would create various problems of equivocal indeterminacy, as Forsey intimates (Forsey, 2013, pp. 212-213).

Importantly, design naturally fits much better with the kinds of aesthetic engagement encouraged by everyday aesthetics, since it has not strictly conformed to traditional artistic aesthetics even while it has an obvious aesthetic sense (Forsey, 2013). The objects of design do not conform strictly 
to art, craft, or even nature; rather, they are part of a more general aesthetic consideration included in basic human ingenuity, which appreciates both environments and the things that transform and improve them. Forsey (2013) is in keeping with Chesterton's view that an engagement with everyday aesthetics implies an improvement of (or addition to) the norm: "Design excellence is extraordinary in the sense that some objects are better than the norm" (Forsey, 2013, p. 241). Aesthetics is thus expanded to include the prosaic without nullifying the possibility of an experience of contingency-sense, wonder, and/ or gratitude-as manifest in sheer delighted surprise. Again, this ratifies the need for an approach to everyday aesthetics for design that is both expansive and restrictive in some sense. Forsey does not explicitly articulate this but a Chestertonian approach helps to highlight such facets even in her work.

Still, this path through design has not generally been followed by scholars of everyday aesthetics. Forsey sees the very problem we have discussed, namely the question of how to set up a foundation for everyday aesthetics. In dialogue with Saito and Haapala, Forsey shows that solid arguments are lacking to make this expansion convenient. She proposes to resolve the ambiguity without resorting to approaches that are alien to what is already part of broad aesthetic theories. After all, aesthetics and the everyday have been intertwined in the essence of design from the beginning. Design interweaves creativity and functional beauty, the natural and the artificial, to set up the possibility of transforming ordinary, daily experiences: "If anything at all can be beautiful, we can also claim that the aesthetic is more closely interwoven with our day-to-day lives than theories that focus on fine art can suggest" (Forsey, 2013, p. 249). In this, Forsey's approach is different from the artistic or restrictive vision of Dewey but, at the same time, separate from the expansive vision of Mandoki in which there is no special focus on everyday things. As she explains, "Design, because of its ubiquity and its embeddedness in our daily lives, can serve to illustrate this importance, and a theory of design can represent the need for a 
realignment of aesthetics as a central part of our philosophical endeavours" (Forsey, 2013, p. 244).

Again, our Chestertonian approach is related to Forsey's (2013) aim, although it helps to highlight certain considerations not overt in Forsey's articulations: "As a mere candidate for aesthetic appreciation, design exemplifies the way that anything at all can be experienced aesthetically, that these experiences can be more common and intimate than those of art" (p. 246). These experiences are fundamental to people who are both creators and users, and who employ design as a means to transform their own environments-and by doing so also communicate their own experiences of everyday aesthetics. In this, people implicitly articulate their more intimate (subjective, everyday, designed) engagements with aesthetics (the objective). This articulation is enmeshed in their needs and feelings, which correspond to personal understandings of what is useful, meaningful, and beautiful. All of this implies a mode of awareness. Indeed, it is in this very awareness, as a restriction of the subject, that there can be an addition to or a revitalization of quotidian singulars. Users and designers become active participants in everyday aesthetics, seeking to render 'ordinary' environments extraordinary. This happens in "active engagement with the object, one that requires various diachronic factors that include familiarity and localized conceptual knowledge" (Forsey, 2013, p. 239). But this active engagement is also highly receptive: decisive, yet open.

Thus, if only provisionally, we can articulate the validity of our Chestertonian approach for supporting thinking about the relationship between design and everyday aesthetics. However else designers and design theorists may consider the way forward for the dialogue between design and everyday aesthetics, at the very least it must account for what Chesterton's own thinking accounts for, which Forsey echoes: a way of working with design's natural engagement with aesthetics without eradicating more personal and subjective aspects. 
Arguably, this Chestertonian everyday aesthetics assumes the very thing that most designers would assume, namely, that it is possible to be surprised by ordinary things. As Forsey writes, "This account of design, having wrested beauty from the narrow domain of the fine arts and having restored it to a place in our daily lives and concerns, in fact contributes to this broader goal of human self-understanding" (Forsey, 2013, p. 251). Therefore, we can support Forsey, who offers the following conclusion in a manner that complements the work of Chesterton:

Design is at times mundane and unexceptional and often overlooked. We do not always approach our cars, toothbrushes, or cubicles with admiration. We do not always make moral or cognitive judgements about our environs and their objects either; an aesthetic response is but one form of response, yet this form contributes equally to what makes us human. (Forsey, 2013, p. 251)

\section{Conclusion}

Above, we have argued that an everyday aesthetics that tries to enhance daily life must be comprised of subjective restrictive attitudes, which revitalize everyday life by welcoming objective expansive patterns. As an approach that stresses the role of mediation in aesthetic experience, this can be termed an expansive-restrictive aesthetics of everyday life. Here, the extension of traditional aesthetics to the everyday is not made from the perspective of an expansive subject, as in Mandoki's work, because such a view excludes the possibility of any real addition to everyday life. Still, it is made in terms of the sense of an expansive object, which includes everyday things. As a corrective to both Mandoki's and Dewey's perspectives, everyday aesthetics requires subjective restrictions, which implicitly acknowledge the limitations and role of subjective mediation. However, such restrictions are not taken from artistic experiences, as in Dewey's work, but rather from an attunement to more basic atmospheric conditions like attitudes, through which the everyday can easily enter and be recognized by the perceiving subject. 
Specifically, Mandoki's expansive aesthetics considers an expansive object (the everyday) because of an expansive subject (aesthesis), whereas Dewey's restrictive aesthetics considers a restrictive object (a qualified experience) because of a restrictive subject (with its focus on unity, structure, and consummation). Expansive-restrictive aesthetics, as exemplified in Chesterton's work, considers an expansive object (the everyday) because of a restrictive experience (delimited by contingency-sense, wonder, and gratitude). In other words, the possibility of an expansive object comes from subjective restrictions. Furthermore, expansive-restrictive aesthetics would support the removal of some traditional aesthetic limitations, like the aesthetic consideration of only artistic objects, and would also support the practical requirement of having a qualified experience in daily life.

The patterns perceptible within environments are containers of everyday things, and since the everyday is not an ambiguous concept, it is rendered meaningful only by the recognition of such patterns, again exemplified by Chesterton. As suggested above, the everyday includes objects and practices that are part of the moment, repetition, and home, as well as specific aesthetic limitations suggested, for example, by the unsightly or grotesque. As further argued above, such an expansive-restrictive aesthetics of everyday life is not foreign to design, as we find considered particularly in Jane Forsey's work. Design already involves an implicit acknowledgement of the need to develop a tension between expansion and restriction with regard to aesthetics, although it has been our aim to begin to articulate more precisely and explicitly how this tension might be delineated. This is something that further research might build on.

Worth noting is the fact that Chestertonian conditions are not restrictive conditions as in Melchionne's definition of the aesthetics of everyday life, although Melchionne tries to be both expansive and restrictive by ensuring 
that the objects to be analysed aesthetically are of a very narrow range: such as food, wardrobes, dwellings, conviviality, and going out (Melchionne and Pérez-Henao, 2017). In an expansive-restrictive aesthetics, everything can be the subject of aesthetic experience, from an artwork to a piece of chalk or a policeman or an accident (See Chesterton, 1909); "such as a scratch or a slight illness, or anything that can be managed with care" (Chesterton, 1986, p. 76). Chesterton writes: "the object of my school is to show how many extraordinary things even a lazy and ordinary man may see if he can spur himself to the single activity of seeing" (Chesterton, 1909, p. 6).

In this way, the theoretical requirement set out at the beginning of this article would be fulfilled: to revitalize everyday life by means of a form of aesthetic consideration. Chesterton fulfils this need, as suggested through a metaphor: "I can imagine no more successful and productive form of manufacture than that of making mountains out of molehills" (Chesterton, 1909, p. 51). Thus, we can answer the principal question in the following way: everyday aesthetics should be expansive (that is, it should concern itself with any aspect of daily life) and restrictive (that is, it should set certain limits on the self and its intentions with regard to the possibilities of aesthetic experience).

\section{References}

Arendt, H. (2006). Eichmann in Jerusalem. A report of the banality of evil. Penguin Books.

Becket, S.J. (2017). The logic of the design problem: A dialectical approach. Design Issues, 33(4), 5-16. https://doi.org/10.1162/Desi_a_00470

Berleant, A. (2005). Ideas for a social aesthetics. En A. Light \& J.M. Smith (Eds.), The aesthetics of everyday life (pp. 23-38). Columbia University Press.

Betts, P. (2004). The authority of everyday objects. University of California Press.

Brady, E. (2012). Smells, tastes, and everyday aesthetics. En D. Kaplan (Ed.). The philosophy of food (pp. 69-86). University of California Press. 
Bustacara, S.M. (2019). En busca de la cocina perdida. Los singulares instantes del quehacer de cocinar. Revista KEPES, 16 (19), 123-149. https://doi.org/10.17151/kepes.2019.16.19.6

Contreras, F.R. (2019). Estudio filosófico sobre la mirada estética en el diseño. Revista KEPES, 16 (19),11-38. https://doi.org/10.17151/kepes.2019.16.19.2

Chesterton, G. K. (2006). Autobiography. Ignatius press.

Ignatius press.

(1986). Collected Works, Vol.1: Heretics, Orthodoxy, The Blatchford Controversies. . (2002). St. Thomas Aquinas, St. Francis of Assisi. Ignatius press. . (1903) Robert Browning. MacMillan. . (1902). Robert Louis Stevenson. Hodder and Stoughton. . (1929). GKC as MC. Methuen. . (1906). Charles Dickens. Dodd, Mead and Company. . (1909) Tremendous Trifles. Dodd, Mead and Company. (1911) Alarms and Discursions. Dodd, Mead and Company.

Desmond, W. (1995). Being and the Between: Political Theory in the American Academy. SUNY Press. (2014). Desire, dialectic, and otherness: an essay on origins.

The Lutterworth Press.

Dewey, J. (2005). Art as experience. The Berkeley Publishing Books.

Dorst, K. (2015). Frame Innovation: Create new thinking by design. MIT.

Forsey, J. (2013). The aesthetics of design. Oxford University Press.

Irvin, S. (2008). The pervasiveness of the aesthetic in ordinary experience. British Journal of aesthetics, 48(1), 29-44. https://doi.org/10.1093/aesthj/aym039

(2009). Aesthetics of the Everyday. A Companion to Aesthetics. 2nd edition. Ed. S.Davies et al. Weley Blackwell.

Fazio, M. (2002). Chesterton, la filosofía del asombro agradecido. Acta Philosophica. Rivista Internazionale di Filosofia, 11 (1), 121-142. 
Jaki, S. (1986). Chesterton: a seer of science. University of Illinois Press.

James, W. (2012). Pragmatism. Renaissance Classics.

Johnson R. V. (2017). Aestheticism, (Vol.3). Taylor and Francis Group.

Kass, L. R. (2005). El alma hambrienta. La comida y el perfeccionamiento de nuestra naturaleza. Ediciones Cristiandad.

Kirshenblatt-Gimblett, B. (1995). The aesthetics of everyday life. En S. Gablik. Conversations before the end of time (pp. 410-433). Thames and Hudson.

Ker, I. (2011). G. K. Chesterton. A biography. Oxford University Press.

Knight, M. (2004). Chesterton and evil. Fordham University Press.

Kupfer, J. (1983). Experience as art: aesthetics in everyday life. State University of New York Press.

Leddy, T. (2005). The nature of everyday aesthetics. En Light, A. \& Smith, J.M. (Eds.), The aesthetics of everyday life (pp. 3-22). Columbia University Press.

Leddy, T. (2012). The extraordinary in the ordinary. Broadview Press.

Leddy, T. y Pérez-Henao, H. (2020). La experiencia del asombro: una aproximación expansiva a la estética cotidiana. Revista KEPES, 17 (22), 397-425. https://doi.org/10.17152/ kepes.2020.17.22.15

Lozano Jiménez, M.Á. y Lapeña Gallego, G. (2018). La poética del diseño en la simbiosis continente-contenido. Aplicación en la tinta de vino. Revista KEPES, 15 (18), 347-372. https://doi.org/10.17151/ kepes.2018.15.18.13

Mandoki, K. (2006). Estética cotidiana y juegos de la cultura. Prosaica I. México, Siglo Veintiuno Editores.

Mandoki, K. (2007). Everyday Aesthetics: Prosaics, the Play of Culture and Social Identities. Ashgate.

Mandoki, K. (2013). El indispensable exceso de la estética. Siglo Veintiuno Editores.

Marini, G. (2021). An Introduction to Everyday Aesthetics in Education. Stud Philos Educ 40, 39 50. https://doi.org/10.1007/s11217-020-09740-x

Melchionne, K. y Pérez-Henao, H. (2017). Definición de estética cotidiana. Revista KEPES, 14 (16), 175-183. https://doi.org/10.17151/kepes.2017.14.16.8 
Milbank, A. (2009). Chesterton and Tolkien as theologians. T \& T Clark.

Novitz, D. (1992). The boundaries of art. Temple University Press.

Pérez-Henao, H. (2014). El lugar de la estética en la vida diaria: historia del concepto de estética cotidiana. Revista Kepes, 10, 227-248.

Pickstock, C. (2013). Repetition and identity. Oxford University Press.

Praz, M. (1988). El pacto con la serpiente. Paralipómenos de La carne, la muerte y el diablo en la literatura romántica. Fondo de Cultura Económica.

Principe, M. (2005). Danto and Baruchello: From art to the aesthetics of everyday. En A. Light \& J.M. Smith. (Eds.) The aesthetics of everyday life (pp. 56-72). Columbia University Press.

Reyburn, D. (2008). Nomads at a crossroads (X-roads): a framework for ethical design in South Africa. Image \& Text a Journal for Design, 14, 6-17.

Romero-Ramírez, M. A. (2019). Estética de lo cotidiano. Un acercamiento desde G. K. Chesterton. Universidad Sergio Arboleda. http://hdl.handle.net/11232/1309

Saito, Y. (2007). Everyday Aesthetics. Oxford University Press.

Saito, Y (2017). Aesthetics of the Familiar: Everyday Life and World-Making. Oxford University Press.

Sartwell, C. (1995). The art of living: aesthetics of the ordinary in world spiritual traditions. SUNY Press.

Smith, A., Byrne, B., Garratt, L., \& Harries, B. (2021). Everyday aesthetics, locality and racialisation. Cultural Sociology, 15(1), 91-112. https://doi.org/10.1177/1749975520949422

Tolkien, J. R. R. (1988). Tree and leaf. Harper Collins.

Wilde, O. (2014). The picture of Dorian Gray. Millennium Publications.

Yarza, I. (2004). Introducción a la estética. EUNSA.

How to cite: Romero-Ramírez, M. A. \& Reyburn, D. (2021). Towards an expansive object and a restrictive experience in Everyday Aesthetics: A Chestertonian metaxological approach. Revista KEPES, 18(24), 197-231. https://doi.org/10.17151/kepes.2021.18.24.8 